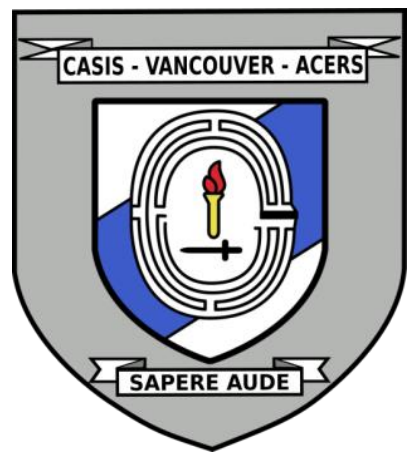

\title{
CANADIAN AMERICAN SOLUTIONS TO THE QUESTIONS OF ARCTIC SECURITY
}

Date: November 22, 2021

Disclaimer: This briefing note contains the encapsulation of views presented by the speaker and does not exclusively represent the views of the Canadian Association for Security and Intelligence Studies.

\section{KEY EVENTS}

On November 22, 2021, Dr. Robert Huebert, Professor at the University of Calgary, presented Canadian American Solutions to the Questions of Arctic Security at the 2021 CASIS West Coast Security Conference. The presentation was followed by a question and answer period with questions from the audience and CASIS Vancouver executives. The key points discussed were Canada's sovereignty in the Arctic, the changing global threat environment, and the USCanada Arctic partnership.

\section{NATURE OF DISCUSSION}

\section{Presentation}

Dr. Huebert's presentation focused on the Arctic security threat environment and the role that environmental security, health security, and cyber security play in it. Some of the new geopolitical challenges faced in the Arctic and possible solutions for Canada to reach appropriate levels of modernization in the Arctic were also discussed.

\section{Question Period}

During the question and answer period, Dr. Huebert expressed that Canada needs to stay aligned with the United States' security and economic policies, follow through on its modernization plans, and enforce its declarations to demonstrate more ownership over Northern passages. 


\section{BACKGROUND}

\section{Presentation}

Dr. Huebert began by noting the complexity of the Arctic security threat environment, such that there is often a tendency to simplify the issues. There is an environmental security threat in the Arctic that can be ranked as existential; for example, climate is having an impact in the Arctic to a level that is of a magnitude greater than anywhere else. Furthermore, health security plays a role in the environment, especially in understanding how COVID-19 has particularly impacted Northern communities. Moreover, adding to the complexity of the environment is cyber-security and the weaponization of social media; a report from the Department's Global Engagement Center suggests that there is reason to believe there has been manipulation in vaxxers vs. anti-vaxxers in the CanadaUS context. In terms of international terrorism, potential future engagement from terrorist organizations will distract states - as it has happened in the past, particularly post 9/11 events-from Arctic security issues. Likewise, focus on domestic terrorism and right-wing extremism will likely result in decision makers placing less emphasis on Arctic security issues.

Dr. Huebert then brought forward the new geopolitical reality between the United States, Russia, and China and stated that the geopolitical Arctic problem is of growing magnitude. Some of the new geopolitical challenges include the renewed Russian assertiveness and the rise of Chinese powers; new weapons systems, which is predicated on new delivery systems and new nuclear warheads that are connected to the Arctic in one way or the other; and weaponization of social media threatening collective security, which Canada and the United States depend on.

Russia's intent and renewed strategic importance of the Arctic can be traced back to 2007: Putin's Munich speech in 2007, resumption of Arctic bomber patrols in 2007, resumption of SSBN Arctic patrols in 2008, resumption of construction of delivery systems for the new submarines, rebuilding and modernizing Northern air bases, and use of force to stop NATO expansion, which accounts for Georgia in 2008 and Ukraine in 2014. When looking at Russia's nuclear modernization, there is the issue of what 'escalate to de-escalate' means, connections of basic principles of state policy issued by the Russian Federation in 2020, and the development of a number of new delivery systems, which Dr, Huebert argues it is about creating the core strategic policy as we move into this new era, and not so much about defending the Arctic continental shelf. 
Regarding China's geopolitics, the vast expansion of their economic system has allowed them to become the 2nd largest defence budget and they have increased the overall international system defending their interests. China's focus has been on the geo-economic factor: the expansion of the Silk Road for a polar component in which they are working closely with Russia in terms of access to oil, gas, and transportation routes. This can be seens as the beginning of them moving for hegemonic control of the international system or just as wanting to play as good actors within the international system, depending on the evidence one focuses on. Dr. Huebert, however, argues that there is a geo-economic Arctic component involved.

Dr. Huebert went on to iterate that the new weapons systems in all major nuclear power holding countries are seeing a fundamental shift. In particular, the United States and Russia are experiencing this shift with respect to what types of weapons and delivery systems they have, as well as what each of these states consider priorities. Due to the geopolitical location of Russia, this results in a significant Arctic focus. The Arctic environment thus becomes about the reality of geopolitical tensions and the development of the new weapons systems, making it an increasingly dangerous situation, for which Canada has to be prepared to respond to. These new systems include the development of hypersonic; autonomous unmanned systems; artificial intelligence; the weaponization of social media; and cyber-warfare, which may not be directed on the Arctic, but includes all elements of the Arctic geopolitical states as it becomes necessary to factor in that adversaries are becoming increasingly apt in figuring out how to divide Western countries.

Regarding Canadian American cooperation, Dr. Huebert pointed out that Canada seems to think it can participate as an equal partner with the United States when it comes to the defence of the North American Arctic region. However, he noted that in reality, the United States is two steps ahead. They look at Russia as a more military aggressive state, and they are rethinking all of their strategies. A commonality between all of these strategies is that they all see Russia as an increasing actual threat and therefore the need to respond with a new series of weapons systems: placing low yield tactical weapons on SSBN, developing hypersonic cruise missiles, developing nuclear capabilities for F-35, building new replacement for Ohio-class submarine, replacing Minuteman ICBM (Intercontinental Ballistic Missile). Dr. Huebert argued that this is both for nuclear deterrence and nuclear war fight, which is a reason for concern since it is a return to a lot of the features of an international system we thought we had left behind. 
Dr. Huebert concluded his presentation by suggesting some solutions at different levels. At the political level, from the basis of a Canadian American issue, include having an ongoing dialogue at the Prime Minister/President level and avoiding or managing the sovereignty issue, which cannot be solved by one state simply claiming access to the passages in the North. At the societal level, Canada and the United States also have to deal with how they respond to 'divide' issues in the north, such as the COVID issue. There has to be a cooperative aspect that society supports; it is not enough only to have intelligence agencies looking at the issues. All Canadian communities must work to stay united in the face of the weaponization of social media and information to achieve collective security. At the constabulary level, not only should the Coast Guards and other first responders cooperate, but the governments should be willing to invest for better responses to environmental, societal, and health crises. Military solutions would include the modernization of NORAD, including modernization of the North Warning System and improvement of Maritime Domain awareness; involvement between NATO and the Arctic; and investment in intelligence gathering capability and replacement of the $\mathrm{CF}-18 \mathrm{~s}$ and submarines to reach appropriate levels of modernization in the Arctic.

\section{Question Period}

During the question and answer period, Dr. Huebert reiterated the importance of on-going dialogue about the Arctic security issues, while also suggesting that Canada needs to follow through on its modernization plans as it emerges in policy conversations. Further, Canada must keep in line with US security and economic policies to be included in aspects of American protectionism; this does not mean a culture change, but just ensuring Canada stays aligned with the United States.

In addressing how other states have impacted Canada's presence on the international stage vis a vis the Arctic, Dr. Huebert provided the example of a New Zealand yacht going through a Northern passage when it was closed due to COVID-19. Dr. Huebert described the Canadian response to New Zealand as a 'slap on the wrist,' and suggested it sends the message that Canada does not think it owns the waters. Dr. Huebert proposed that instead Canada should have stopped the vessel to show it was following through on enforcing its declarations.

\section{KEY POINTS OF DISCUSSION}

\section{Presentation}

The Journal of Intelligence, Conflict, and Warfare Volume 4, Issue 3 
- Environmental security, health security, and cyber security play a role in the Arctic security threat environment, making it highly complex and increasingly dangerous.

- Russia's renewed assertiveness, the rise of Chinese powers, new weapons systems, and threats to collective security are some of the new geopolitical challenges in the Arctic.

- Although cyber warfare might not be directed on the Arctic, it includes all elements of the Arctic geopolitical states as it becomes necessary to factor in how adversaries plan to divide Western countries.

- Canada seems to think it can participate as an equal partner with the United States when it comes to the defence of the North American Arctic region, but the reality is that the United States is two steps ahead.

- To reach appropriate levels of modernization in the Arctic, changes at the political, societal, constabulary, and military levels are needed.

\section{Question Period}

- Canada needs to stay aligned with the United States' security and economic policies and follow through on its modernization plans.

- Canada needs to enforce its declarations to demonstrate more ownership over Northern passages.

\section{(c) (1) ()}

EY NC ND This work is licensed under a Creative Commons Attribution-NonCommercial-NoDerivatives 4.0 International License.

(C) (ROBERT HUEBERT, 2022)

Published by the Journal of Intelligence, Conflict, and Warfare and Simon Fraser University

Available from: https://jicw.org/ 